\title{
CEsifo WORKING

\section{Trust in Government and Compliance With Stay at Home Orders in American States}

Oguzhan C. Dincer 


\section{Impressum:}

CESifo Working Papers

ISSN 2364-1428 (electronic version)

Publisher and distributor: Munich Society for the Promotion of Economic Research - CESifo

$\mathrm{GmbH}$

The international platform of Ludwigs-Maximilians University's Center for Economic Studies and the ifo Institute

Poschingerstr. 5, 81679 Munich, Germany

Telephone +49 (0)89 2180-2740, Telefax+49 (0)89 2180-17845, email office@cesifo.de

Editor: Clemens Fuest

https://www.cesifo.org/en/wp

An electronic version of the paper may be downloaded

- from the SSRN website: www.SSRN.com

- from the RePEc website: $\quad$ www.RePEc.org

- from the CESifo website: https://www.cesifo.org/en/wp 


\title{
Trust in Government and Compliance With Stay at Home Orders in American States
}

\begin{abstract}
Trust in government is particularly important in implementing public health policies especially during crises such as the COVID-19 pandemic. This study investigates the effects of trust in government and compliance with stay at home orders using data from American states during the first wave of the pandemic. A system of four seemingly unrelated regression (SUR) equations covering four consecutive Saturdays starting with April 25 is estimated with maximum likelihood. The regression results indicate that people are more likely to comply with stay at home orders in more trusting states.
\end{abstract}

JEL-Codes: I180, D700, D730.

Keywords: trust in government, Covid-19, social distancing.

Oguzhan C. Dincer

Department of Economics

Illinois State University

Campus Box 4200

USA - 61790-4200, Normal, IL

odincer@ilstu.edu 
During the first wave of the COVID-19 pandemic most of the states issued stay at home orders as part of their social distancing policies to prevent the spread of the virus. Schools, restaurants, and bars were closed, and all nonessential businesses were ordered to keep workers home and let them work remotely. The order was mandatory in some states and advisory in others. People were asked not to leave their homes unless necessary. Americans’ compliance with the stay at home orders varied significantly across the states. In some states such as Michigan, protesters armed with assault rifles rallied in the state capitol building not once but three times in May.

In their study published in Public Administration Review in COVID-19 Viewpoint Symposium, Christensen and Lægreid (2020) hypothesized that Norway’s success of handling the pandemic was mostly due to its government's legitimacy. According to a recent survey conducted by Helsingen et al. (2020), almost 99\% of Norwegians complied with the preventive measures taken by the government in March including the draconian ones such as curfews. Although the measures were not enforced, people responded to the government's appeal to trust in their government and their willingness to help out in a national emergency positively (Christensen and Lægreid 2020, 777).

Christensen and Lægreid (2016) define government legitimacy as the belief that government does what is desirable, appropriate, and fair. It increases compliance with government policies (Marien and Hooghe 2011). Legitimacy of a government depends on how trustworthy it is (Christensen and Lægreid 2005). Trust in government is particularly important in implementing public health policies especially during crises such as the COVID-19 pandemic. Several studies find that trust in government explains people’s behavior towards public health policies such as social distancing. Helsingen et al. (2020), 
using individual survey data from Norway and Sweden, and Robinson et al. (2020) from America, both find that people who trust in their governments are more likely to comply with social distancing policies. Empirical evidence from earlier public health crises such as the Ebola epidemic support their findings. Blair et al. (2017) and Vinck et al. (2019) both find that low trust in government explains lower compliance with social distancing and lower acceptance of a vaccine in Liberia and Democratic Republic of Congo, respectively. ${ }^{1}$

In this study, Christensen and Lægreid’s (2020) hypothesis regarding the relationship between trust in government and compliance with social distancing policies is tested using data from American states during the first wave of the COVID-19 pandemic. The study is organized as follows. In the next section, data and estimation method are described. The results are presented and discussed in the following two section. The last section concludes the study.

\section{Estimation Method and Data}

The following system of four seemingly unrelated regression (SUR) equations is estimated with maximum likelihood:

Shelter in Place Index I,April $18=\beta_{0}+\beta_{1} \cdot$ Trust in Government $_{i}$

$$
+\beta_{2} \cdot \text { COVID-19 Positive }{ }_{i, \text { April 16 }}+X_{i}^{\prime} \beta_{j}+u_{i, \text { April } 18}
$$

Shelter in Place Index $x_{i, \text { April } 18}=\alpha_{0}+\alpha_{1} \cdot$ Trust in Government ${ }_{i}$

$$
+\alpha_{2} \cdot \text { COVID-19 Positive }{ }_{i, \text { April 23 }}+X_{i}^{\prime} \alpha_{j}+\varepsilon_{i, \text { April } 25}
$$

Shelter in Place Index ${ }_{i, \text { April 18 }}=\gamma_{0}+\gamma_{1} \cdot$ Trust in Government ${ }_{i}$

$$
+\gamma_{2} \cdot \text { COVID-19 Positive }_{i, \text { April 30 }}+X_{i}^{\prime} \gamma_{j}+\mu_{i, \text { May } 02}
$$

Shelter in Place Index ${ }_{i, \text { April 18 }}=\delta_{0}+\delta_{1} \cdot$ Trust in Government ${ }_{i}$

$$
+\delta_{2} \cdot \text { COVID-19 Positive }{ }_{i, \text { May } 07}+X_{i}^{\prime} \delta_{j}+v_{i, \text { May } 09}
$$


where Shelter in Place Index represents an index constructed by SafeGraph. It measures people's compliance with stay at home orders which very is challenging. Previous studies using individual surveys such as Helsingen et al. (2020) and Robinson et al. (2020) construct indices based on self-reported data. The Shelter in Place Index is constructed based on observed data. Using anonymized data representing 45 million smartphones, Shelter in Place Index represents the change (as a difference) in the percentage of people staying home compared to baseline. The index ranges from -100 to 100 , where 0 (zero) is no change from baseline. Home refers to the most common nighttime location in recent months identified to a precision of about 100 square meters. Baseline is defined as the average percent of people staying home each day across the seven days ending February 12, 2020. If, for example, the baseline percentage of people staying home for a state is 20 and 30 percent of the population is staying home on March 27th, then the index for March 27th is $30-20=10 .^{2}$ Observed data are more reliable than self-reported data due to possible social desirability bias when it comes to compliance with preventive health measures. Social desirability is major source response bias in survey research. It refers to the survey respondents' tendency to draw a favorable picture of themselves, i.e., the tendency to underreport socially undesirable behavior and overreport the socially desirable ones (DeMaio 1985). Henry et al. (1992), for example, find that emergency department doctors and nurses significantly overreport their use of gloves, gowns, masks, and goggles.

The data cover four consecutive Saturdays starting from April 18. Between midApril and mid-May, stay at home orders were in place in all states but 5 (Arkansas, Connecticut, Nebraska, North Dakota, and Wyoming). ${ }^{3}$ Compliance with the stay at 
home orders varies significantly across states and over time. Between April 18 and May 9, when COVID-19 related deaths peaked in both states, while the Shelter in Place Index in California ranged between 17.64 and 20.86 it ranged between 9.61 and 14.92 in Georgia.

Measuring legitimacy at the state level is as challenging as measuring compliance with stay at home orders. Trust in Government is a crucial determinant of legitimacy and it is widely used in the literature as a measure (see Gilley 2006, 2012, Levi et al. 2009). Sampling in American National Election Study (ANES) and General Social Survey (GSS), the two frequently used surveys in the literature which ask questions regarding trust in government is done at the national level, not at the state level. The COVID-19 Consortium for Understanding the Public's Policy Preferences Across States (COVID States Project) which is a joint project of The Network Science Institute of Northeastern University, The Shorenstein Center on Media, Politics, and Public Policy of Harvard University, and School of Communication and Information, Rutgers University conducted 50 state survey weighted for race/ethnicity, age, and gender in each state at the end of April measuring trust in several people and organizations ranging from state governments to pharmaceutical companies to Joe Biden in handling the COVID-19 pandemic. The following question was asked to each participant:

How much do you trust the following people and organizations to do the right thing to best handle the current coronavirus (COVID-19) outbreak?

The four-point response scale ranges from "a lot" to "not at all”. Percentage of respondents who trust their state government "a lot" is used as the measure of 
government legitimacy in this study. There is a significant variation across the states in terms of the level of trust in government as well. While in Massachusetts more than 50 percent of the respondents trust their state government “a lot”, it is only 20 percent of respondents in Idaho. Figure 1 shows the relationship between Trust in Government and Shelter in Place Index in the states which issued a stay at home order during the time period investigated in this study.

COVID-19 Positive represents the percentage of people tested positive for COVID-19 in each state on four consecutive Thursdays starting from April 16. Since higher positivity rate indicates a higher infection risk, people are expected to comply with social distancing orders more.

$X$ represents the set of economic and demographic control variables used in ML estimation. The economic control variables are median income (Income) and unionization rate (Union). Social distancing is costlier for lower income people who are mostly essential workers with little to no savings making it more difficult to comply with stay at home orders. But unionized workers had various health and safety and financial protections due to their collective bargaining agreements. General Motors, Ford, and Fiat Chrysler, for example, paused operations for two weeks in late March to slow the spread of the virus after negotiating with the United Auto Workers. The Communications Workers of America successfully negotiated additional paid sick and family leave for unionized Verizon workers (McNicholas et al. 2020).

The demographic control variables are population (Population), urbanization (Urban), and the percentage of people whore older than 64 (Old). According to several surveys conducted by Gallup in March, Americans who live in more populated and more 
urbanized states are likely to comply with social distancing orders. ${ }^{4}$ The same applies for the states with oldest population since older people are more vulnerable to COVID-19. Variable definitions, data sources, and summary statistics are given in Table 1.

Each Saturday from April 18 to May 9 forms one fourth of the system. Because it allows errors to be correlated across the equations, estimating a SUR system with ML is more efficient than estimating each equation individually with Ordinary Least Squares (OLS).

\section{Results}

The ML estimates with robust standard errors clustered at the state level are presented in Table 2. First, a parsimonious model with only COVID-19 Positive and Trust in Government is estimated, followed by the full model including all economic and demographic control variables. The estimated coefficient of Trust in Government is positive and statistically significant in all four equations indicating that people are more likely to comply with stay at home orders in more trusting states. The coefficient estimates of equation 4 indicates that a 1 standard deviation increase in Trust in Government causes Shelter in Place Index to increase by 0.2 deviations. This is not trivial. The estimated standardized coefficients of COVID-19 Positive and Log Income are 0.3. and 0.45, respectively. Estimated coefficients of the control variables are also statistically significant and they all have the expected signs. Positivity rate is certainly one of the most important determinants of stay at home behavior. Across all four equations the estimated coefficient is positive, and its magnitude does not fluctuate. In populated and urbanized states people stay at home more. Cost of staying at home 
matters as well. In states with higher median incomes in which workers are unionized compliance with stay at home orders is higher.

\section{Digression: Trusting the State Government vs. Trusting Donald Trump}

In late April, Donald Trump started showing his opposition to the preventive measures including stay at home orders issued by individual states. On one late Friday night, he posted a trio of tweets calling for the "liberation” of Michigan, Minnesota, and Virginia. In his news conferences during late April and early May he asked for individual states to relax the social distancing policies arguing that the spread of the virus was slowing down. During May, there were protests in most states. To investigate the effects of Donald Trump’s behavior on people’s compliance with stay at home orders, the SUR system is re-estimated for the three Saturdays following Donald Trump's infamous tweet of April 17 including a new variable, Trust in Donald Trump. The data again are from the COVID States Project and the variable is measured as the percentage of people who trust Donald Trump “a lot”. The results are given in Table 3. As expected, Trust in Donald Trump is negative and statistically significant (albeit only marginally in equation 2). Perhaps more interestingly, the magnitudes of the estimated coefficients of Trust in Donald Trump and Trust in Government are not statistically significantly different from each other. In other words, Trust in Donald Trump wipes out the positive effects of Trust in Government on compliance with stay at home orders.

\section{Discussion}

The results presented above have important implications regarding vaccinating people against COVID-19. According to Anthony Fauci, the most prominent U.S. infectious disease expert, herd immunity against COVID-19 requires vaccination rates approaching 
as high as 90 percent. ${ }^{5}$ Will 90 percent of the population accept to be vaccinated, when the vaccine is available widely? According to Larson et al. (2018) vaccine acceptance depends on multiple levels of trust: trust in the vaccine, trust in the health professionals providing and administering the vaccine, and trust in government approving and recommending the vaccine. Trust in government also affects social trust (Levi 1998, Levi and Stoker 2000, Rothstein 2000, 2005) which in turn affects vaccine acceptance. Freimuth et al. (2017), for example, find that even when racial and ideological variables are controlled for, there is a positive relationship between social trust and vaccine acceptance (for influenza vaccine) using a national sample 800 Black and White Americans.

Vaccinating millions of Americans against COVID-19 creates an opportunity for state governments for building trust. Although there are federal guidelines regarding the distribution of the vaccine both across and within the states, state governors decide on who receives the first doses of the vaccine and who administers them. Failure to distribute and administrate the vaccine fairly and effectively will cause significant damage to trust in government. Florida, for example, is a complete mess. Governor of Florida decided to vaccinate people 65 and older even before the most essential workers but left the administration of the vaccine to the counties. Lee County in Southwest Florida had a first-come first-serve approach which led to people camping out overnight to get vaccinated. ${ }^{6}$ In Palm Beach County, while wealthy people with connections get vaccinated, others were told the wait, possibly months. Adding to the mess, the Florida Division of Emergency Management announced the temporary closure of its coronavirus testing and vaccination site at Hard Rock Stadium in Miami Gardens because of the 
College Football Playoff national championship game. ${ }^{7}$ This is bad news for Florida as the percentage of people who trust the state government in Florida already falls into the lowest quartile.

\section{Conclusion}

Government legitimacy plays a crucial role in successful implementation of public health policies. According to Christensen and Lægreid (2020), Norway’s success of handling the COVID-19 pandemic was mostly due to its government's legitimacy. A vast majority of Norwegians complied with the social distancing orders issued by the government because they trust their government. In this study, the relationship between trust in government and compliance with stay at home orders is investigated using data from American states. The regression results indicate that there is indeed a positive relationship between the two. In terms of policy, this suggests that states such Oklahoma, South Dakota, Mississippi, Georgia, Alabama, Florida and Idaho in which the trust in government is low, need the help of trusted personalities to legitimize the public health policies. Donald Trump, who is trusted more than the governments in these states, made it only worse by opposing the stay at home orders. Illinois, on the other hand, launched an "all in" campaign at the beginning of April, asking Illinoisans to comply with the stay at home orders. The campaign was very successful partly because local celebrities ranging from hip hop artist Chance the Rapper to Chicago Blackhawks right winger Patrick Kane to comedian Jane Lynch were heavily involved. 


\section{Endnotes}

1. For other studies regarding the relationship between trust in government and vaccination, see Nawa and Fujiwara (2019) for Japan, Chuang et al. (2015) for Taiwan, and Yaqub et al. (2014) for Germany, UK, France, Italy, and Spain.

2. See safegraph.com for details.

3. See Moreland et al. (2020).

4. Lydia Saad, "Americans Rapidly Answering the Call to Isolate, Prepare”, gallup.com, March 20, 2020.

5. Jonathan Allen, "Fauci Says Herd Immunity Could Require Nearly $90 \%$ to Get Coronavirus Vaccine”, reuterts.com, December 24, 2020.

6. Eric Levenson, Angela Barajas and Ryan Young, "Florida's First-Come, First-Serve COVID-19 Vaccination Plan for the Elderly Leads to Scramble." CNN.com, December 30, 2020.

7. Patricia Mazzei, Eric Adelson and Kate Kelly, "It Became Sort of Lawless: Florida Vaccine Rollout Turns into a Free-for-All”, New York Times, January 10, 2021. 


\section{References}

Blair, Robert A., Benjamin S. Morse, and Lily L. Tsai. 2017. "Public Health and Public Trust: Survey Evidence from the Ebola Virus Disease Epidemic in Liberia.” Social Science \& Medicine 172: 89-97.

Gilley, Bruce. 2006. “The Meaning and Measure of State Legitimacy: Results for 72 Countries.” European Journal of Political Research 45 (3): 499-525.

—. 2012. “State Legitimacy: An Updated Dataset for 52 Countries.” European Journal of Political Research 51 (5): 693-699.

Christensen, Tom, and Per Lægreid. 2005. "Trust in Government: The Relative Importance of Service Satisfaction, Political Factors, and Demography.” Public Performance \& Management Review 28 (4): 487-511.

_. 2020. "Balancing Governance Capacity and Legitimacy: How the Norwegian Government Handled the COVID-19 Crisis as a High Performer." Public Administration Review 80 (5): 774-79.

Christensen, Tom, Per Lægreid, and Lise H. Rykkja. 2016. “Organizing for Crisis Management: Building Governance Capacity and Legitimacy.” Public Administration Review 76 (6): 887-97.

Chuang, Ying-Chih, Ya-Li Huang, Kuo-Chien Tseng, Chia-Hsin Yen, and Lin-hui Yang. 2015. "Social Capital and Health-Protective Behavior Intentions in an Influenza Pandemic.” PLOS ONE 10 (4): e0122970.

DeMaio, Theresa. 1984. “Social Desirability and Survey Measurement: A Review.” In Surveying Subjective Phenomena, edited by Charles Turner and Elizabeth Martin. New York: Russell Sage Foundation.

Freimuth, Vicki S., Amelia M. Jamison, Ji An, Gregory R. Hancock, and Sandra Crouse Quinn. 2017. "Determinants of Trust in the Flu Vaccine for African Americans and Whites.” Social Science \& Medicine 193: 70-79.

Helsingen, Lise M., Erle Refsum, Dagrun Kyte Gjøstein, Magnus Løberg, Michael Bretthauer, Mette Kalager, and Louise Emilsson. 2020. “The COVID-19 Pandemic in Norway and Sweden - Threats, Trust, and Impact on Daily Life: A Comparative Survey.” BMC Public Health 20 (1). 
Henry, Keith, Scott Campbell, and Myra Maki. 1992. “A Comparison of Observed and Self-Reported Compliance with Universal Precautions among Emergency Department Personnel at a Minnesota Public Teaching Hospital: Implications for Assessing Infection Control Programs.” Annals of Emergency Medicine 21 (8): 940-46.

Larson, Heidi J., Richard M. Clarke, Caitlin Jarrett, Elisabeth Eckersberger, Zachary Levine, Will S. Schulz, and Pauline Paterson. 2018. "Measuring Trust in Vaccination: A Systematic Review.” Human Vaccines \& Immunotherapeutics 14 (7): 1599-1609.

Levi, Margaret. 1998. “A State of Trust.” In Trust and Governance, edited by Valerie Braithwaite and Margaret Levi. New York: Russell Sage Foundation.

Levi, Margaret, Audrey Sacks, and Tom Tyler. 2009. “Conceptualizing Legitimacy, Measuring Legitimating Beliefs.” American Behavioral Scientist 53 (3): 354-75.

Levi, Margaret, and Laura Stoker. 2000. "Political Trust and Trustworthiness.” Annual Review of Political Science 3 (1): 475-507.

Marien, Sofie, and Marc Hooghe. 2011. “Does Political Trust Matter? An Empirical Investigation into the Relation between Political Trust and Support for Law Compliance.” European Journal of Political Research 50 (2): 267-91.

McNicholas, Celine, Lynn Rhinehart, Margaret Poydock, Heidi Shierholz, and Daniel Perez. 2020. "Why Unions Are Good for Workers_Especially in a Crisis like COVID-19.” Washington, DC: Economic Policy Institute.

Moreland, Amanda. 2020. “Timing of State and Territorial COVID-19 Stay-at-Home Orders and Changes in Population Movement — United States, March 1-May 31, 2020.” MMWR. Morbidity and Mortality Weekly Report 69.

Nawa, Nobutoshi, and Takeo Fujiwara. 2019. “Association between Social Capital and Second Dose of Measles Vaccination in Japan: Results from the A-CHILD Study.” Vaccine 37 (6): 877-81.

Robinson, Scott E., Joseph T. Ripberger, Kuhika Gupta, Jennifer A. Ross, Andrew S. Fox, Hank C. Jenkins-Smith, and Carol L. Silva. 2020. “The Relevance and Operations of Political Trust in the COVID-19 Pandemic." Public Administration Review, forthcoming. 
Rothstein, Bo. 2000. “Trust, Social Dilemmas and Collective Memories.” Journal of Theoretical Politics 12 (4): 477-501.

- 2005. Social Traps and the Problem of Trust. Cambridge: Cambridge University Press.

Vinck, Patrick, Phuong N Pham, Kenedy K Bindu, Juliet Bedford, and Eric J Nilles. 2019. "Institutional Trust and Misinformation in the Response to the 2018-19 Ebola Outbreak in North Kivu, DR Congo: A Population-Based Survey.” The Lancet Infectious Diseases 19 (5): 529-36.

Yaqub, Ohid, Sophie Castle-Clarke, Nick Sevdalis, and Joanna Chataway. 2014.

“Attitudes to Vaccination: A Critical Review.” Social Science \& Medicine 112: $1-11$. 
Figure 1. Trust in Government and Shelter in Place Index

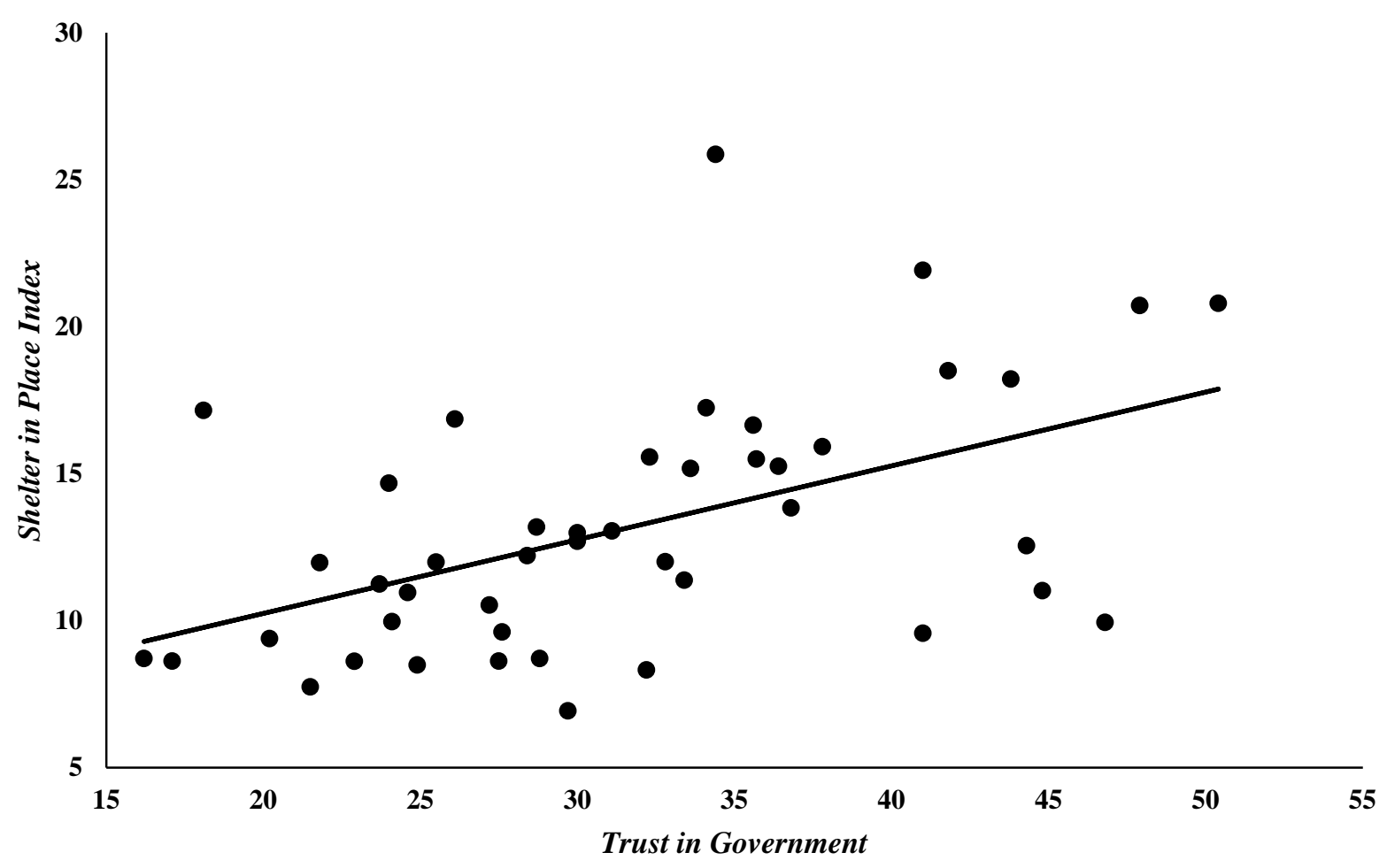


Table 1. Summary Statistics

\begin{tabular}{|c|c|c|c|c|}
\hline & Mean & Std. Dev. & Min. & Max. \\
\hline \multicolumn{5}{|l|}{ Shelter in Place Index } \\
\hline April 18, 2020 & 16.204 & 4.214 & 10.370 & 29.050 \\
\hline April 25, 2020 & 13.088 & 4.201 & 6.910 & 26.080 \\
\hline May 2, 2020 & 11.344 & 4.532 & 4.220 & 24.260 \\
\hline May 9, 2020 & 11.872 & 4.363 & 5.660 & 24.040 \\
\hline \multicolumn{5}{|l|}{ COVID-19 Positive } \\
\hline April 16, 2020 & 12.819 & 9.363 & 2.560 & 49.606 \\
\hline April 23, 2020 & 13.017 & 9.255 & 2.265 & 49.957 \\
\hline April 30, 2020 & 12.450 & 8.765 & 1.877 & 47.859 \\
\hline May 7, 2020 & 11.816 & 8.220 & 1.536 & 45.662 \\
\hline Trust in Government & 31.480 & 8.552 & 16.200 & 50.400 \\
\hline Trust in Donald Trump & 25.668 & 5.823 & 11.600 & 41.400 \\
\hline Income & 61,549 & 10,184 & 44,097 & 83,242 \\
\hline Union & 11.531 & 5.199 & 3.600 & 24.400 \\
\hline Urban & 74.166 & 14.775 & 38.700 & 95.000 \\
\hline Old & 16.506 & 1.970 & 11.100 & 20.600 \\
\hline Population & $6,550,675$ & $7,389,282$ & 578,759 & $39,512,223$ \\
\hline $\begin{array}{l}\text { Data Sources: } \\
\text { Shelter in Place Index: SafeG } \\
\text { COVID-19 Positive: COVID } \\
\text { Legitimacy: COVID States PI } \\
\text { Income, Union, Urban, Old, }\end{array}$ & $\begin{array}{l}\text { ah (safegraph.c } \\
\text { acking Project } \\
\text { ect (covidstate } \\
\text { oulation: U.S. }\end{array}$ & $\begin{array}{l}\text { cking.com) } \\
\text { ureau (census }\end{array}$ & & \\
\hline
\end{tabular}


Table 2. Maximum Likelihood SUR Estimation

Dependent Variable: Log Shelter in Place Index

\begin{tabular}{|c|c|c|c|c|c|c|c|c|}
\hline \multirow[b]{2}{*}{ COVID-19 Positive } & \multicolumn{2}{|c|}{$\begin{array}{c}\text { Equation 1 } \\
\text { April 18, } 2020\end{array}$} & \multicolumn{2}{|c|}{$\begin{array}{c}\text { Equation } 2 \\
\text { April 25, } 2020 \\
\end{array}$} & \multicolumn{2}{|c|}{$\begin{array}{c}\text { Equation } 3 \\
\text { May 2, } 2020 \\
\end{array}$} & \multicolumn{2}{|c|}{$\begin{array}{c}\text { Equation } 4 \\
\text { May 9, } 2020 \\
\end{array}$} \\
\hline & $\begin{array}{l}.210 \\
(.005)^{* * *}\end{array}$ & $\begin{array}{l}.177 \\
(.002)^{* * *}\end{array}$ & $\begin{array}{l}.206 \\
(.005)^{* * *}\end{array}$ & $\begin{array}{l}.156 \\
(.002)^{* * *}\end{array}$ & $\begin{array}{l}.188 \\
(.006)^{* * *}\end{array}$ & $\begin{array}{l}.141 \\
(.002)^{* * *}\end{array}$ & $\begin{array}{l}.195 \\
(.006)^{* * *}\end{array}$ & $\begin{array}{l}.161 \\
(.002)^{* * *}\end{array}$ \\
\hline Legitimacy & $\begin{array}{l}.175 \\
(.057)^{* * *}\end{array}$ & $\begin{array}{l}.057 \\
(.015)^{* * *}\end{array}$ & $\begin{array}{l}.160 \\
(.060)^{* * *}\end{array}$ & $\begin{array}{l}.042 \\
(0.020)^{* *}\end{array}$ & $\begin{array}{l}.221 \\
(.066)^{* * *}\end{array}$ & $\begin{array}{l}.082 \\
(.021)^{* * *}\end{array}$ & $\begin{array}{l}.227 \\
(.061)^{* * *}\end{array}$ & $\begin{array}{l}.095 \\
(.021)^{* * *}\end{array}$ \\
\hline Log Income & & $\begin{array}{l}10.707 \\
(1.354)^{* * *}\end{array}$ & & $\begin{array}{l}8.728 \\
(1.714)^{* * *}\end{array}$ & & $\begin{array}{l}12.138 \\
(1.659)^{* * *}\end{array}$ & & $\begin{array}{l}12.069 \\
(1.492)^{* * *}\end{array}$ \\
\hline Union & & $\begin{array}{l}.071 \\
(.043)^{*}\end{array}$ & & $\begin{array}{l}.104 \\
(.037)^{* * *}\end{array}$ & & $\begin{array}{l}.097 \\
(.036)^{* * *}\end{array}$ & & $\begin{array}{l}.107 \\
(0.040)^{* * *}\end{array}$ \\
\hline Urban & & $\begin{array}{l}.081 \\
(.017)^{* * *}\end{array}$ & & $\begin{array}{l}.097 \\
(.019)^{* * *}\end{array}$ & & $\begin{array}{l}.096 \\
(.017)^{* * *}\end{array}$ & & $\begin{array}{l}.073 \\
(.015)^{* * *}\end{array}$ \\
\hline Old & & $\begin{array}{l}.299 \\
(.095)^{* * *}\end{array}$ & & $\begin{array}{l}.315 \\
(.098)^{* * *}\end{array}$ & & $\begin{array}{l}.514 \\
(.090)^{* * *}\end{array}$ & & $\begin{array}{l}.504 \\
(.096)^{* * *}\end{array}$ \\
\hline Log Population & & $\begin{array}{l}.363 \\
(.204)^{*}\end{array}$ & & $\begin{array}{l}.705 \\
(.190)^{* * *}\end{array}$ & & $\begin{array}{l}.554 \\
(.222)^{* *}\end{array}$ & & $\begin{array}{l}.341 \\
(.214)\end{array}$ \\
\hline Constant & $\begin{array}{l}7.993 \\
(1.847)^{* * *}\end{array}$ & $\begin{array}{l}-123.128 \\
(16.111)^{* * *}\end{array}$ & $\begin{array}{l}5.362 \\
(1.940)^{* * *}\end{array}$ & $\begin{array}{l}-110.752 \\
(19.144)^{* * *}\end{array}$ & $\begin{array}{l}2.051 \\
(2.236)\end{array}$ & $\begin{array}{l}-151.875 \\
(18.321)^{* * *}\end{array}$ & $\begin{array}{l}2.404 \\
(2.117)\end{array}$ & $\begin{array}{l}-146.187 \\
(16.146)^{* * *}\end{array}$ \\
\hline
\end{tabular}


Table 3. Maximum Likelihood SUR Estimation

Dependent Variable: Log Shelter in Place Index

\begin{tabular}{|c|c|c|c|}
\hline & $\begin{array}{c}\text { Equation 1 } \\
\text { April 25, } 2020 \\
\end{array}$ & $\begin{array}{c}\text { Equation } 2 \\
\text { May 2, 2020 } \\
\end{array}$ & $\begin{array}{c}\text { Equation } 3 \\
\text { May 9, 2020 } \\
\end{array}$ \\
\hline COVID-19 Positive & $\begin{array}{l}.162 \\
(.002)^{* * *}\end{array}$ & $\begin{array}{l}.146 \\
(.002)^{* * *}\end{array}$ & $\begin{array}{l}.169 \\
(.002)^{* * *}\end{array}$ \\
\hline Trust in Government & $\begin{array}{l}.039 \\
(.019)^{*}\end{array}$ & $\begin{array}{l}.079 \\
(.019)^{* * *}\end{array}$ & $\begin{array}{l}.089 \\
(.018)^{* * *}\end{array}$ \\
\hline Trust in Donald Trump & $\begin{array}{l}-.059 \\
(.033)^{*}\end{array}$ & $\begin{array}{l}-.054 \\
(.039)\end{array}$ & $\begin{array}{l}-.088 \\
(.034)^{* * *}\end{array}$ \\
\hline Log Income & $\begin{array}{l}7.308 \\
(1.908)^{* * *}\end{array}$ & $\begin{array}{l}10.843 \\
(1.768)^{* * * *}\end{array}$ & $\begin{array}{l}9.948 \\
(1.489)^{* * *}\end{array}$ \\
\hline Union & $\begin{array}{l}.109 \\
(.036)^{*}\end{array}$ & $\begin{array}{l}.103 \\
(.034)^{* * *}\end{array}$ & $\begin{array}{l}.118 \\
(0.039)^{* * *}\end{array}$ \\
\hline Urban & $\begin{array}{l}.095 \\
(.018)^{* * *}\end{array}$ & $\begin{array}{l}.094 \\
(.016)^{* * *}\end{array}$ & $\begin{array}{l}.071 \\
(.012)^{* * *}\end{array}$ \\
\hline Old & $\begin{array}{l}.227 \\
(.120)^{*}\end{array}$ & $\begin{array}{l}.434 \\
(.120)^{* * *}\end{array}$ & $\begin{array}{l}.373 \\
(.107)^{* * *}\end{array}$ \\
\hline Log Population & $\begin{array}{l}.654 \\
(.195)^{* * *}\end{array}$ & $\begin{array}{l}.512 \\
(.219)^{* *}\end{array}$ & $\begin{array}{l}.278 \\
(.187)\end{array}$ \\
\hline Constant & $\begin{array}{l}-91.253 \\
(22.833)^{* * *}\end{array}$ & $\begin{array}{l}-134.160 \\
(20.903)^{* * *}\end{array}$ & $\begin{array}{l}-117.274 \\
(16.665)^{* * *}\end{array}$ \\
\hline
\end{tabular}

Robust standard errors (clustered at the state level) in parentheses. ${ }^{* * *},{ }^{* *}$, and ${ }^{*}$ represent statistical significance levels at $1 \%, 5 \%$, and $10 \%$ levels, respectively. Breusch-Pagan test for the independence of residuals is rejected at the $1 \%$ significance level for both specifications. 